\title{
The structure of the Heath Steele Mines region, Bathurst Camp, New Brunswick
}

\author{
J.A. de Roo*, C. Moreton, P.F. Williams \\ Department of Geology, Box 4400, University of New Brunswick, Fredericton, New Brunswick E3B 5A3, \\ Canada
}

and

\author{
C.R. van Staal** \\ Lithosphere and Canadian Shield Division, Geological Survey of Canada, 601 Booth Street, \\ Ottawa, Ontario K1A 0E8, Canada
}

Date Received July 10, 1989

Date Accepted November 13, 1989

\begin{abstract}
This paper deals with the structure of the region surrounding Heath Steele Mines, which is situated in the southern part of the Ordovician volcanic-sedimentary complex of the Bathurst Camp, New Brunswick. In this area, five generations of deformation structures are recognized on the basis of orientation, tectonic style, and systematic overprinting relationships.

The earliest recognizable deformation $\left(D_{1}\right)$ is characterized by tight to isoclinal $F_{1}$ folds of a compositional layering $\left(S_{2}\right)$. A cleavage $\left(S_{1}\right)$ parallel to the axial plane of these folds was locally rotated into a transposition foliation $\left(S_{2}\right)$ during the $D_{2}$ deformation. Where gently dipping, $S_{2}$ was cast into domes and basins in two events $\left(D_{v}\right.$ and $\left.D_{5}\right)$ of upright folding with axial plane cleavages $S_{v}$ and $S_{s}$. Where steeply dipping, $S_{2}$ was subjected to recumbent folding $\left(D_{h}\right)$ prior to the fifth deformation $\left(D_{s}\right)$. Overprinting relationships between the $D_{v}$ and $D_{h}$ events are ambiguous, so their correlation with the third and fourth deformations remains open to interpretation.

The macroscopic structure in the Heath Steele Mines area is dominated by an open fold (the North Little River Lake Fold) of a belt of metasedimentary rocks and augen schists. This belt is host to the Heath Steele sulphide orebodies and is also an $F_{1}$ fold zone. The age of the macroscopic fold is not well constrained, but the asymmetry of second-order $F_{2}$ folds reverses across its hinge, and its southwestern limb is attenuated in a zone of high $\mathrm{D}_{2}$ strain, suggesting that it is an $\mathrm{F}_{2}$ fold. The zone of high $\mathrm{D}_{2}$ strain separates the folded belt of metasedimentary rocks and augen schists from a pod of massive porphyry and granitoid rocks.
\end{abstract}

Cet article porte sur la structure de la région entourant les mines Heath Steele et se situant dans la partie méridionale du complexe volcano-sédimentaire ordovicien de Bathurst Camp, au Nouveau-Brunswick. Dans cette région, l'orientation des structures, le style tectonique et le caractère systématique des superpositions permettent de reconnaître cinq épisodes de déformation.

La déformation la plus ancienne à être reconnue $\left(\mathrm{D}_{1}\right)$ se caractérise par des plis $\mathrm{F}_{1}$ serrés à isoclinaux affectant un rubanement de composition $\left(\mathrm{S}_{0}\right)$. Une schistosité $\left(\mathrm{S}_{1}\right)$, parallèle à la surface axiale de ces plis, se modifia localement, par rotation, en une foliation de transposition $\left(\mathrm{S}_{2}\right)$ durant la déformation $\mathrm{D}_{2}$. Là où son pendage était faible, $\mathrm{S}_{2}$ prit la forme de dômes et cuvettes en deux épisodes $\left(D_{v}\right.$ et $\left.D_{s}\right)$ de plissement vertical accompagnés de schistosités de surface axiale $S_{v}$ et $S_{s}$. Là où son pendage était élevé, $S_{2}$ fut soumise à un plissement couché $\left(D_{h}\right)$ précédant la cinquième déformation $\left(D_{s}\right)$. Les superpositions relatives des épisodes $D_{v}$ et $D_{b}$ sont ambigües; leur corrélation avec les troisième et quatrième déformations reste à déterminer.

\footnotetext{
*Current Address: Institut für Geologie und Dynamik der Lithosphäre, Georg-August Universität, Goldschmidtstrasse 3, D-3400 Göttingen, West Germany
}

**Geological Survey of Canada Contribution Number 30389

\section{ATLANTIC GEOLOGY}

$26,27-41(1990)$ 
La structure macroscopique dans les mines Heath Steele est dominée par un pli ouvert (le pli de North Little River Lake) au sein d'une ceinture de schistes oeillés et de roches métasédimentaires. Cette ceinture est l'hôte des gisements de sulfures de Heath Steele et elle est aussi une zone de plis $\mathrm{F}_{1}$. L'âge du pli macroscopique n'est pas bien délimité, mais l'asymétrie des plis de deuxième ordre $\mathrm{F}_{2}$ se renverse à travers sa chamière et son flanc sud-ouest est atténué dans une zone où la contrainte $\mathrm{D}_{2}$ est élevée, ce qui porte à croire qu'il s'agit d'un pli $\mathrm{F}_{2}$. Cette zone de contrainte $\mathrm{D}_{2}$ élevée sépare la ceinture plissée de roches métasédimentaires et de schistes oeillés d'une intumescence de porphyre et de roches granitoïdes massifs.

[Traduit par le joumal]

\section{INTRODUCTION}

This paper presents the results of a structural analysis of the Heath Steele Mines region, which is situated in the Bathurst Mining Camp of northem New Brunswick (Fig. 1). This study formed part of a government-funded project, specifically aimed at achieving a better understanding of the geometry and evolution of the base metal sulphide deposits (de Roo et al., unpublished data). The regional mapping was supported by satellite image analysis and geophysical surveys, and also by a programme of trenching, conducted jointly with Noranda Exploration.

The Bathurst Camp contains a number of stratabound massive sulphide deposits, classified as volcanogenic by McAllister (1960), Harley (1979) and Franklin et al. (1981). They are hosted by a sequence of mafic and felsic volcanic and sedimentary rocks of the Ordovician Tetagouche Group (Skinner, 1974), which is within the Miramichi Tectonic Zone of the northern Appalachians (Fyffe et al., 1981; Davies et al., 1983; van Staal, 1987). In the Bathurst Camp the Tetagouche Group defines an arcuate complex, in which stratigraphy is difficult to establish because of lack of fossil control, complex primary facies changes and intense deformation (Skinner, 1974). Initial sedimentation is inferred to have terminated in the Early Ordovician, preceding a stage of felsic volcanism that was accompanied in the Middle Ordovician by mafic volcanism and renewed sedimentation (Helmstaedt, 1971; Davies et al., 1983; van Staal, 1987). The Tetagouche Group was intruded by felsic plutons and gabbro, prior to regional low-grade metamorphism and deformation (Helmstaedt,1971; Skinner, 1974; Irrinki, 1986; van Staal, 1987). A younger, more regional suite of bimodal intrusions accompanied renewed deformation, attributed to the Acadian orogeny by Fyffe et al. (1981).

\section{THE GEOLOGY OF THE HEATH STEELE MINES REGION}

Detailed mapping in the Heath Steele Mines region (Fig. 2) is hindered not only by the poor stratigraphic facies control, but also by poor exposure and lithological changes because of penetrative, locally intense, deformation (Fig. 3). Rock units may also be in tectonic contact with their neighbours, so structural analysis cannot rely on elaborate stratigraphy. We refer to existing lithographies (Davies et al., 1983; Moreton and Williams, 1986; van Staal, 1987), but for mapping purposes, the various rock types have simply been grouped into seven units (Fig. 2).

One lithological unit is defined by phyllitic rocks of clastic and/or volcaniclastic origin. The metasedimentary rocks are juxtaposed with quartz ( \pm feldspar) augen schists. Contacts between the two units are mostly sharp. The augen schists grade into felsic schists and phyllites, which contain horizons of metaagglomerate. In domains of low strain, the phyllites grade into metarhyolite with relict amygdaloidal and spherulitic textures. Greenschists and green phyllites are also present. Pillow structures are locally preserved, indicating a mafic volcanic origin for some of these rocks. Some greenschists grade into massive metadiabase, which can be mapped as a separate unit. Massive quartz metaporphyry forms another lithological unit, located southwest of the Heath Steele Mines. The metaporphyry grades into foliated metagranitic rocks, which are presumably of Ordovician age (Fyffe et al., 1977, 1981; van Staal, 1987).

The five major sulphide deposits ("A"-"E"; Fig. 2) at Heath Steele Mines are located at, or near, contacts between the metasedimentary rocks and the augen schists (McBride, 1976; Owsiacki, 1980). The contacts are also marked by mineral prospects, local sulphide disseminations and iron enrichments. In the mining area (between " $B$ " and "D" in Fig. 2), the metasedimentary rocks and augen schists occupy elongate domains with a westerly strike. These domains are spatially associated, so that both rock types and their contacts define a mineralized belt. This belt stands out on Landsat images and airborne geophysical survey maps, and is warped into a broad arc west of the mine area (the North Little River Lake (NLRL) Fold; Figs. 1, 2). This fold has been subdivided into two structural domains, first of which is the northeastern limb of the fold. Because of poor exposure and consequent shortage of data, the hinge and southeastern limb of the fold were combined to form the second domain. A third tectonic domain has been distinguished on the basis of its generally weak foliation. This domain is also characterized by a large pod of quartz metaporphyry, and is here referred to as the "Porphyry Pod" (Fig. 1). The Porphyry Pod is separated from the folded belt of metasedimentary rocks and augen schists by a northwesterly striking zone of intensely folded rocks with strong foliations and lineations.

Polyphase deformation was recognized in key outcrops in each domain (Fig. 3). The distinction of successive generations of structures in these outcrops has been based on overprinting relationships on micro- and mesoscopic scales. Sets of structures were then correlated between outcrops using a combination of criteria, including style, orientation, and/or age, relative to other structures present. This procedure resulted in identification of five generations of structures $\left(D_{1}, D_{2}, D_{v}, D_{b}, D_{s}\right)$ in the Heath Steele Mines region (Table 1).

The structural analysis concentrated on the mine area, so the structure of the northeastern limb of the NLRL Fold is discussed first. Next, the structural relationships are extrapolated to key outcrops in the two other tectonic domains. 


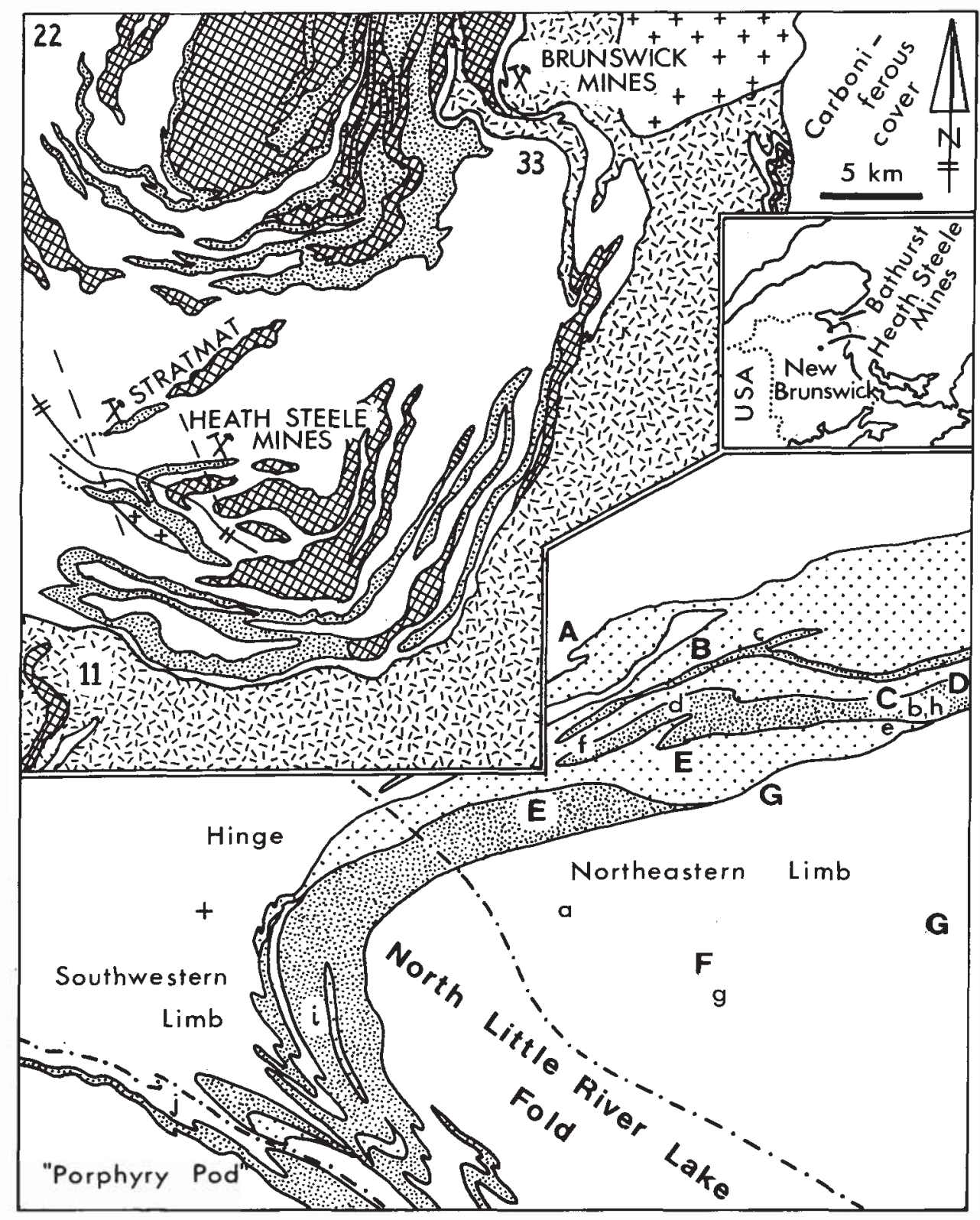

Fig. 1. Map of the southeastern part of the Bathurst Camp, New Brunswick (after Davies et al., 1983; van Staal, 1987). Crosses = granite and metagranitoid rocks; white $=$ felsic schist and metavolcanic rocks; hatching = mafic metavolcanic rocks, metagabbro, metadiabase; fine stipple = metasedimentary rocks, green phyllite; snow pattern = quartzite and phyllite. Dashes and form line refer to Figure 10. The map below highlights the belt of metasedimentary rocks (fine stipple) and augen schist (open stipple) at Heath Steele Mines. The fold in this belt (the North Little River Lake Fold) is dissected into two tectonic domains: one is the northeastern fold limb, the other consists of the hinge and southwestern limb. The "Porphyry Pod" constitutes a third domain. Dash-dots are domain boundaries. A-G mark the tectonic subdomains in Figure 7; a-j refer to Figure 3. 11, 22, and 33 (upper map) refer to Table 1.

\section{THE NORTHEASTERN LIMB OF THE NORTH LITTLE RIVER LAKE FOLD}

\section{Small-scale structures}

The earliest deformation $\left(D_{1}\right)$ is represented by $F_{1}$ folds of tension veins and of a compositional layering ( $\mathrm{S}_{0}$; Fig. 3a). Locally, $\mathrm{S}_{0}$ is marked by a preferred mineral orientation (Moreton and Williams, 1986). This fabric may well be tectonic in origin, but could also represent mimetic growth of phyllosilicates after primary fabrics (Williams, 1972; Maltman, 1981; Weber, 1981). The $F_{1}$ folds are accompanied by an axial plane cleavage $\left(S_{1}\right)$ that in some rocks is defined by spaced, stylolitic seams of opaque minerals and phyllosilicates. In pelites, $S_{1}$ is commonly a differentiated layering. Although strongly refracted across parts of the deformed layering, $S_{1}$ is generally parallel to $S_{0}$ (Fig. $3 a)$, and the presence of rootless $F_{1}$ folds within the layering is further indication of $F_{1}$ transposition of $S_{0}$ into $S_{1}$. The transposition foliation $S_{1}$ tends to dip steeply to the south (Fig. 4a), and locally contains an extension lineation $\left(\mathrm{L}_{1}\right.$; Fig. $\left.4 \mathrm{c}\right)$. This 


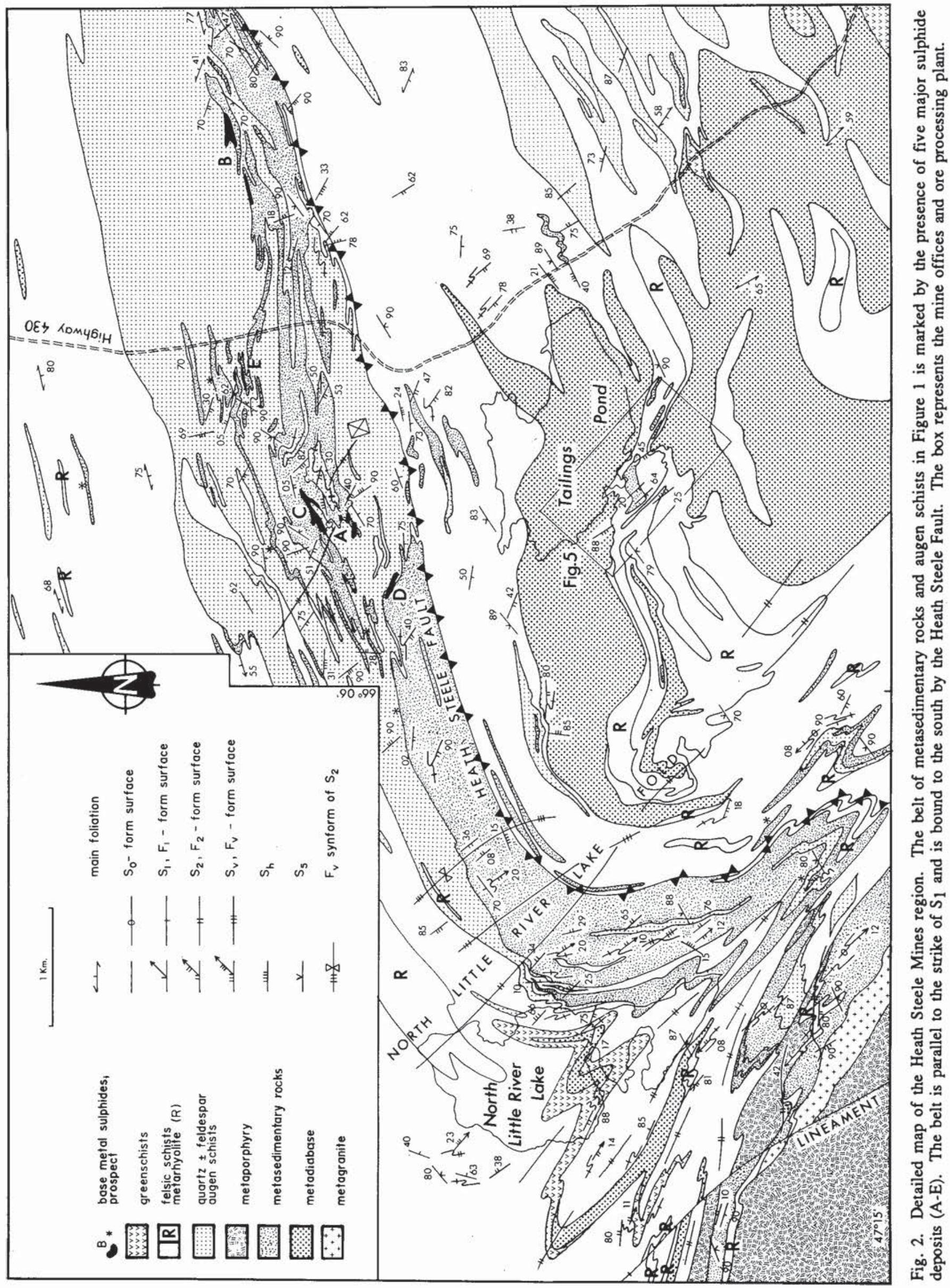




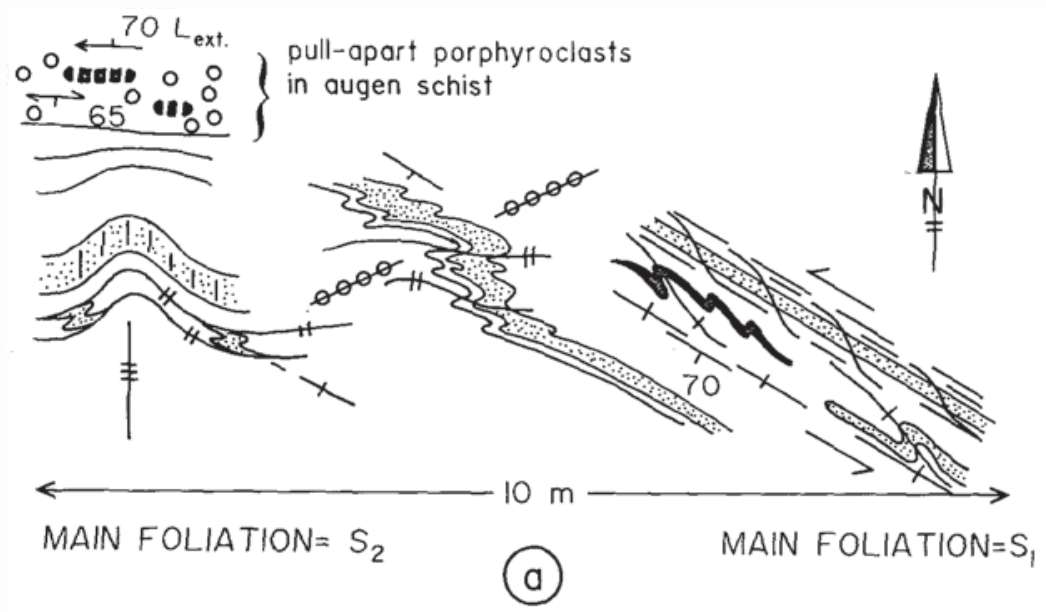

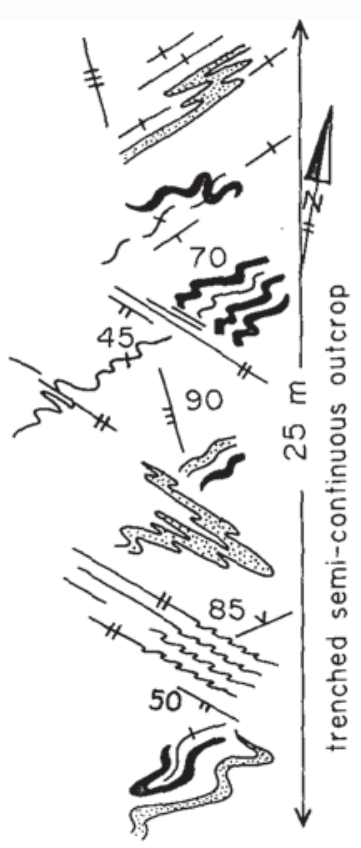

(d)

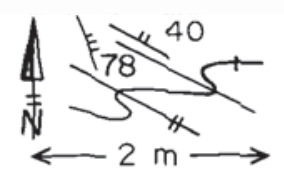

(e)

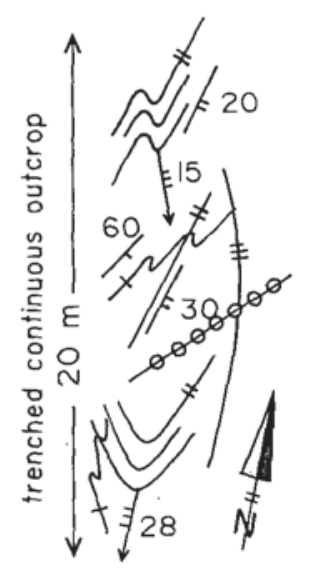

(f)

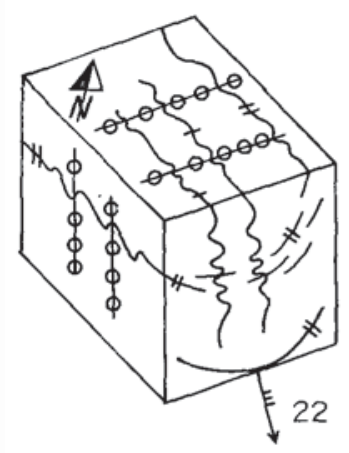

(b)

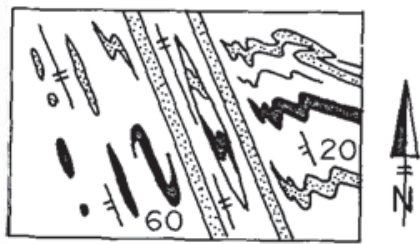

$\longleftrightarrow 10 \mathrm{~m} \longrightarrow$ continuous outcrop

(g)

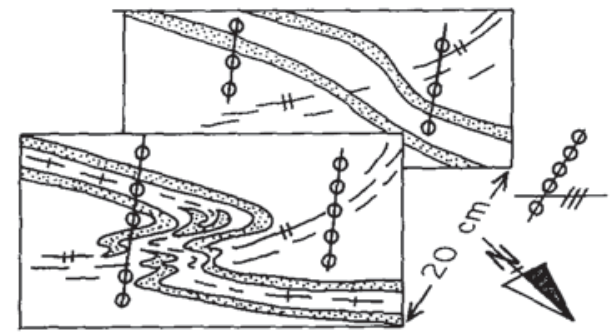

(c)

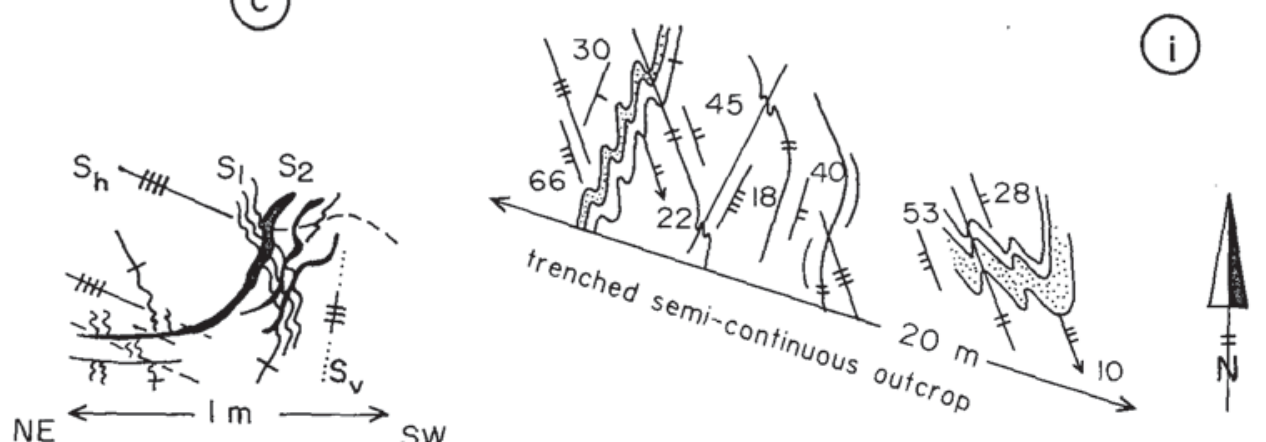

(h)

(j)
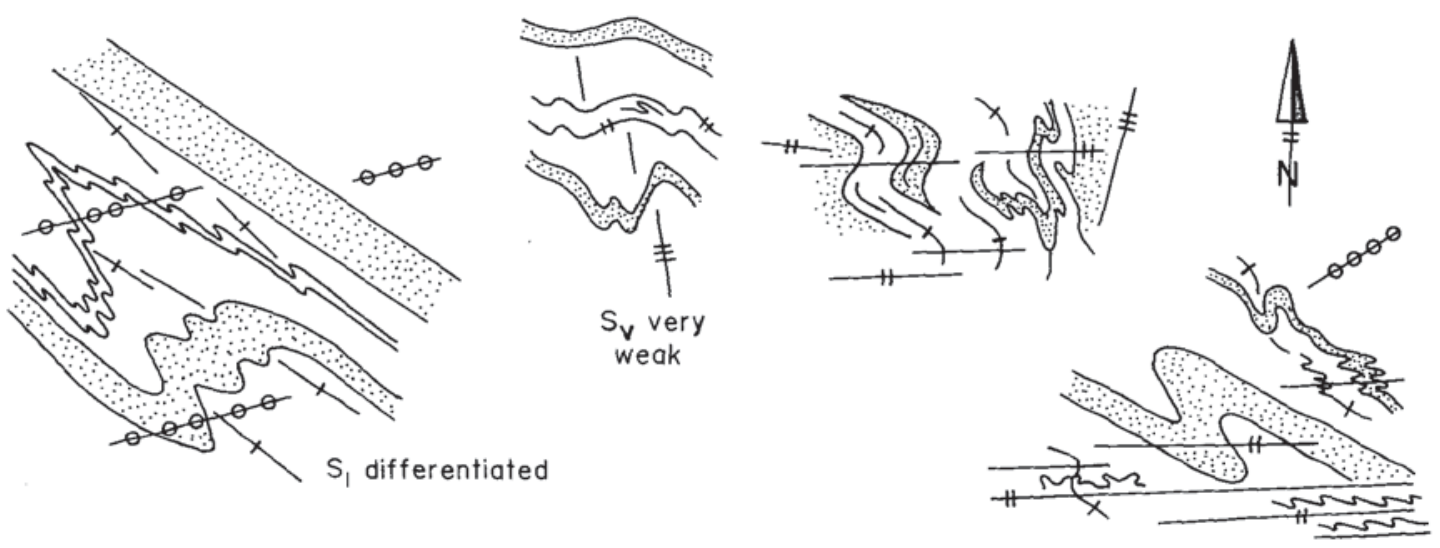

$20 \mathrm{~m}$

$S_{1}$ and $S_{2}$ differentiated

Fig. 3. (a-j) Field sketches: for location see Figure 1. Black = vein (differentiated cleavage in $h$ ); "pearl strings" $=S_{5}$ form surface; other structural symbols as in Figure 2. Note that $(\mathrm{h})$ is a section, and that (b) and (c) are viewed in perspective; the other sketches represent plans. 
de ROO ET AL.

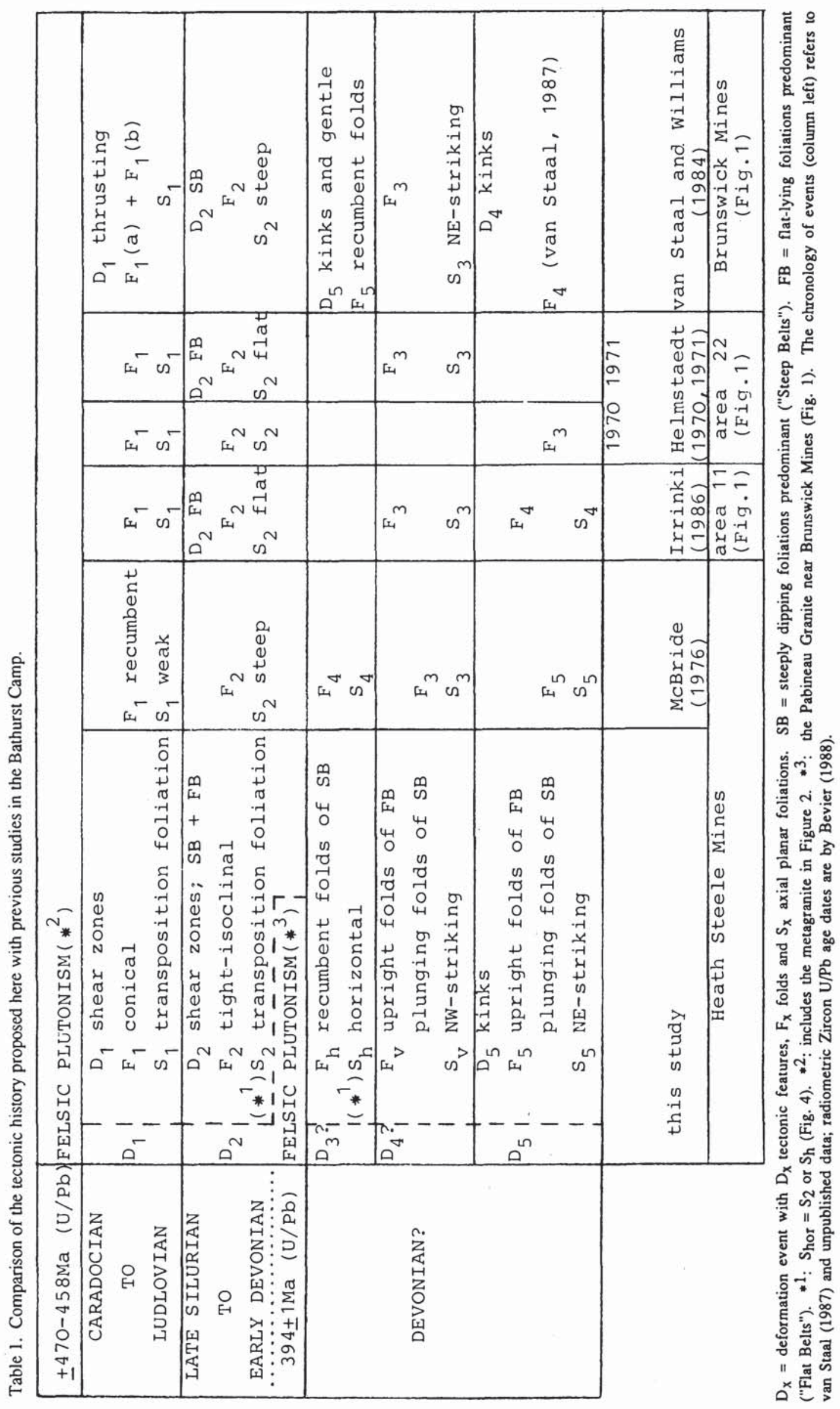




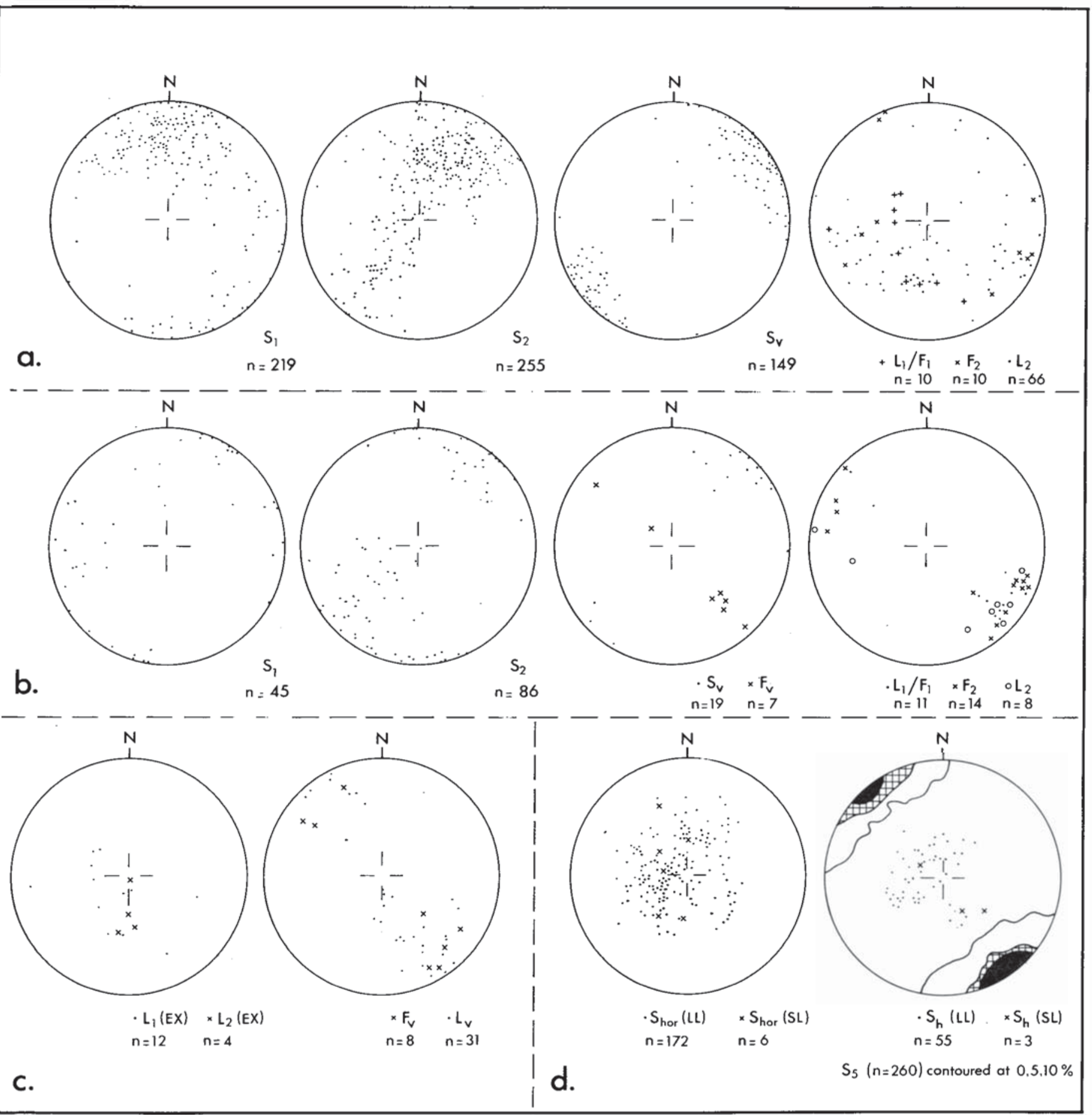

Fig. 4. Lower hemisphere of equal area projections, showing poles to planes $\left(\mathrm{S}_{\mathrm{x}}\right)$, fold axes $\left(\mathrm{F}_{\mathrm{x}}\right)$, intersection lineations $\left(\mathrm{L}_{\mathrm{x}}\right)$, and extension lineations $\left(\mathrm{L}_{\mathrm{ex}}\right.$ ). (a) Plots from the northeastem limb (LL) of the North Little River Lake Fold; (b) plots from the southwestern limb (SL) and hinge of this fold; (c) plots of $D_{1} / D_{2}$ extension lineations and of $D_{v}$ linear elements from the LL fold domain; (d) plots of " $S_{\text {hor }}$ " $\left(=S_{2}\right.$ or $\left.S_{b}\right)$, and of a combination of $S_{h}$ and $S_{5}$. Both plots combine data from both limbs $(S L+L L)$ of the fold. The clusters of $S_{s}$ poles have been contoured.

lineation is defined by a phyllosilicate preferred orientation and by microboudinaged porphyroclasts of feldspar and quartz (de Roo and Williams, unpublished data).

$S_{1}$ is overprinted by $F_{2}$ folds with an $S_{2}$ axial plane cleavage. $S_{2}$ is locally a differentiated crenulation cleavage. At present, $S_{2}$ varies in orientation between flat-lying and subvertical, but generally strikes west-northwest (Fig. 4a). Some $F_{2}$ folds of $S_{1}$ are intrafolial in $\mathrm{S}_{2}$, indicating local $\mathrm{F}_{2}$ transposition of $\mathrm{S}_{1}$. The variation in the intensity of $F_{2}$ folding and $S_{2}$ cleavage development suggests a heterogeneous $\mathrm{D}_{2}$ strain distribution, which explains why the dominant foliation in outcrops throughout the area can be $S_{1}$ or $S_{2}$ (Fig. 3a-d). The orientation relationships 
between $S_{1}$ and $S_{2}$ have been further complicated by refraction of $S_{2}$ across the $S_{1}$ transposition layering (see also van Staal and Williams, 1984). In view of the local $F_{2}$ transposition, the subvertical mineral lineation in $\mathrm{S}_{2}$ (Fig. 4c) could be interpreted as a rotated $L_{1}$ extension lineation.

The third and fourth deformations $\left(\mathrm{D}_{3}\right.$ and $\left.\mathrm{D}_{4}\right)$ comprise folds with vertical and horizontal axial planar cleavages. Age relationships between these deformations are inconclusive, so they are referred to as $D_{v}$ ("vertical") and $D_{b}$ ("horizontal"), respectively (Table 1). $D_{v}$ is represented in outcrop by a weak crenulation cleavage $\left(S_{v}\right)$ in the axial plane of open $F_{v}$ folds of $\mathrm{S}_{2}$ (Fig. 3a, b, f). $\mathrm{S}_{v}$ has a northwesterly strike (Fig. 4a). A moderately dipping cleavage with a similar strike was observed in several locations, but could not be distinguished clearly as $\mathrm{S}_{2}$ or $\mathrm{S}_{v}$. Such surfaces are omitted from Figure 4, so that the average dip of $S_{v}$ may be exaggerated. Most $F_{v}$ fold axes and $L_{v}$ lineations plunge gently to the northwest or southeast (Fig. 4c), indicating that $F_{v}$ folds are upright and noncylindrical. Upright $F_{v}$ folds alone cannot explain the present orientation distribution of $\mathrm{S}_{2}$ (Fig. 4a), but there are also recumbent folds, representing the fourth, or third, deformation $\left(D_{b}\right)$.

The $F_{b}$ folds are open, locally chevron-style, structures or small crenulations. Their axial planes are marked by a horizontal, or gently dipping, crenulation cleavage ( $\mathrm{S}_{\mathrm{b}}$; Fig. $\left.4 \mathrm{~d}\right)$ ). $\mathrm{S}_{\mathrm{b}}$ has been observed only locally, but is typically well developed where it does occur, suggesting $S_{b}$ is a penetrative structure that is regionally present. In the absence of overprinting relationships, flatlying foliations can be either $\mathrm{S}_{2}$ or $\mathrm{S}_{b}$ (= " $\mathrm{S}_{\text {bor }}$ "; Fig. 4d), and a distinction between the two is possible only where $S_{2}$ is moderately or steeply dipping in part of the outcrop (Fig. 3h). This distinction is complicated further by lack of conclusive overprinting relationships between $D_{v}$ and $D_{b}$ structures. In outcrops where both $S_{v}$ and $S_{b}$ are present as cleavages, $S_{b}$ is better developed, but locally undulates and assumes the same strike as $\mathrm{S}_{\mathrm{v}}$ (as in Fig. 3h), indicating that $\mathrm{S}_{\mathrm{b}}$ predates $\mathrm{S}_{\mathrm{v}}$ (Table 1).

Upright folds and crenulations of the flat-lying cleavages, and steeply plunging folds of $\mathrm{S}_{v}$, mark a fifth deformation $\left(\mathrm{D}_{s} ; \mathrm{S}_{s}\right.$ in Fig. 3b, c, f). $D_{s}$ structures also include spaced kinks, which rarely occur in conjugate pairs. The folds are accompanied by an axial planar crenulation cleavage $\left(\mathrm{S}_{5}\right)$ that is easily recognized as a vertical foliation of evenly spaced, dark seams, striking southwest (Figs. 2, 4d).

\section{Large-scale structures: the Tailings Pond quarries}

Good exposure in quarries to the south of the mine area (Figs. 2,5 ) allowed correlation of the small-scale structural observations with the macroscopic structure. The latter is outlined by detailed mapping of lithological boundaries. In the quarry area, metasedimentary rocks occupy the central part of an overall westerly striking sequence, and are flanked on either side by felsic phyllites and schists, metarhyolite, and massive metadiabase. The metasedimentary rocks have a distinctive compositional layering $\left(\mathrm{S}_{0}\right)$, the strike of which is mostly parallel to the strike of a slaty cleavage $\left(S_{1}\right) . S_{1}$ is axial planar to tight or isoclinal $F_{1}$ folds of the layering, indicating transposition of the layering into $S_{1}$. Thus, the mesoscopic $F_{1}$ transposition, the general parallelism between $S_{1}$ and the trend of lithological boundaries, and the symmetrical distribution of rock types relative to the metasedimentary rocks suggest that the latter mark the hinge of a macroscopic $\mathrm{F}_{1}$ fold of $\mathrm{S}_{0}$ (Figs. 5, 6a; $\mathrm{S}_{1}$ form surface).

The $F_{1}$ fold has been overprinted by an asymmetrical $F_{2}$ fold, which is the dominant structure in Figure 5. On the mesoscopic scale, $F_{1}$ folds are also deformed by $F_{2}$ folds, which have the same asymmetry as the macroscopic structure. A southwesterly dipping cleavage $\left(\mathrm{S}_{2}\right)$ is present in the axial planes of the $\mathrm{F}_{2}$ folds. At " $K$ " (Figs. 5,6), $S_{2}$ is a crenulation cleavage of $S_{1}$, but in westerly and easterly directions away from this point $S_{1}$ is progressively transposed into $S_{2}$ By the obliteration of $S_{1}$ a domainal $S_{2}$ slaty cleavage is established, in which the preexisting layering is either dissected and drawn out into augen, or is preserved in intrafolial $\mathrm{F}_{2}$ folds (Fig. $3 \mathrm{~g}$ ). This transition mainly reflects $\mathrm{D}_{2}$ strain gradients normal to $S_{2}$, although $D_{2}$ strain also varies in a direction parallel to the strike of $S_{2}$. The $D_{2}$ deformation concentrated in two narrow shear zones, extending from $A$ to $A^{1}$, and from $B$ to $B^{1}$ (Figs. 5, 6). The $S_{0}$-trend has been rotated into parallelism with these zones, and various lithological units can be found in narrow lenses and mesoscopic boudins along the shear zones. This indicates that the overall asymmetry of the $\mathrm{F}_{2}$ fold in Figure 5 is the result of the attenuation of its limbs in $\mathrm{D}_{2}$ shear zones.

Along a traverse from point " $\mathrm{K}$ " to the attenuated limbs of the $\mathrm{F}_{2}$ fold, both the $\mathrm{D}_{2}$ strain and the dip of $\mathrm{S}_{2}$ increase (Fig. $3 \mathrm{~g}$ ). At " $K$ ", a steeply dipping cleavage $\left(S_{v}\right)$ can be distinguished from $\mathrm{S}_{2}$ Although there are no mesoscopic $\mathrm{F}_{\mathrm{v}}$ folds at this site, $\mathrm{S}_{\mathrm{v}}$ and $\mathrm{S}_{2}$ locally have a similar strike, suggesting that the rotation of $\mathrm{S}_{2}$ resulted from open $\mathrm{F}_{\mathrm{v}}$ folding. These relationships imply that in plan view the axial plane of the macroscopic $\mathrm{F}_{2}$ fold is also the axial plane of an $F_{v}$ monoclinal flexure of $S_{2}$ (Fig. $6 \mathrm{a}$ ).

\section{Large-scale structures of $S_{1}$ and $S_{2}$ : evaluation of orientation distributions}

$S_{1}$ and $S_{2}$ are generally similar in style, and both can be transposition foliations. Because of $F_{1}$ transposition, $S_{0}$ has not been distinguished from $S_{1}$ in the plot of the $S_{1}$ orientation distribution in Figure $4 a$, and $S_{1}$ and $S_{2}$ were only recorded where the two could be separated. Nevertheless, some of the readings of $S_{2}$ in Figure 4 are bound to represent transposed $S_{1}$ planes. Consequently, the plot of poles to $S_{1}$ is incomplete, and biased toward orientations that meet the overprinting criteria in the key outcrops. In order to further investigate the spatial relationship between $S_{1}$ and $S_{2}$, the northeastem limb of the NLRL Fold was divided into 7 structural subdomains (Fig. 1A-G), and poles to $S_{1}$ and $\mathrm{S}_{2}$ were plotted per subdomain (Fig. 7).

Subdomain $\mathrm{F}$ represents the Tailings Pond quarries, in which $S_{1}$ and $S_{2}$ can be clearly defined in outcrop. Nevertheless, both cleavages show almost the same orientation distribution (Fig. 7F). Plots of the other subdomains show different clusters for $S_{1}$ and $S_{2}$, and indicate that $S_{1}$ either dips steeply to the south (Fig. 7B, E), or is subvertical, striking west-southwest (Fig. 7A, G). The two preferred $S_{1}$ - strike-trends reflect the two strike trends of lithological contacts in the belt of metasedimentary rocks and augen schists: contacts north of the mine buildings 


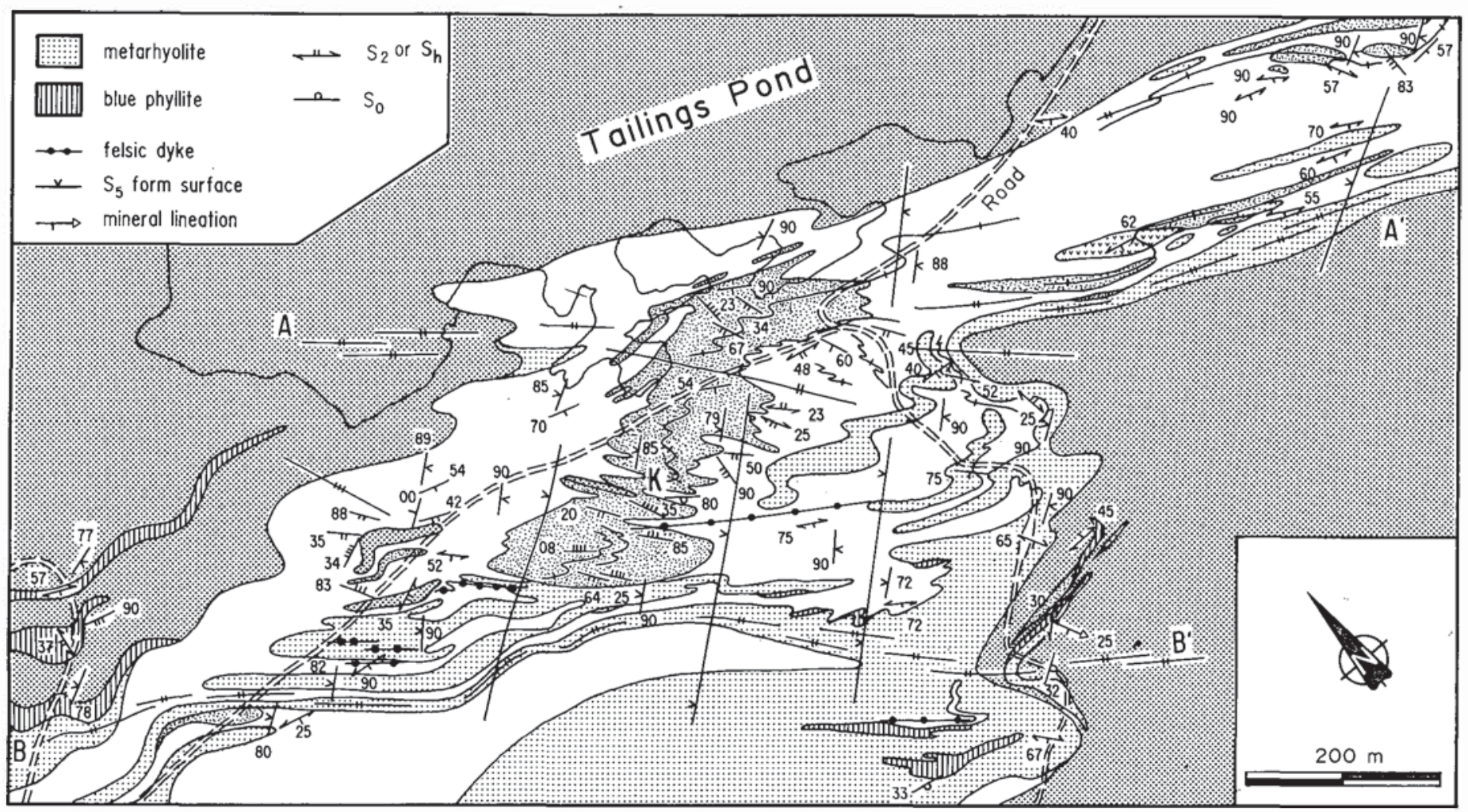

Fig. 5. Structural map of the quarry area south of the mine tailings pond. Legend as in Figure 2 unless indicated. For location, see Figure 2 (frame).
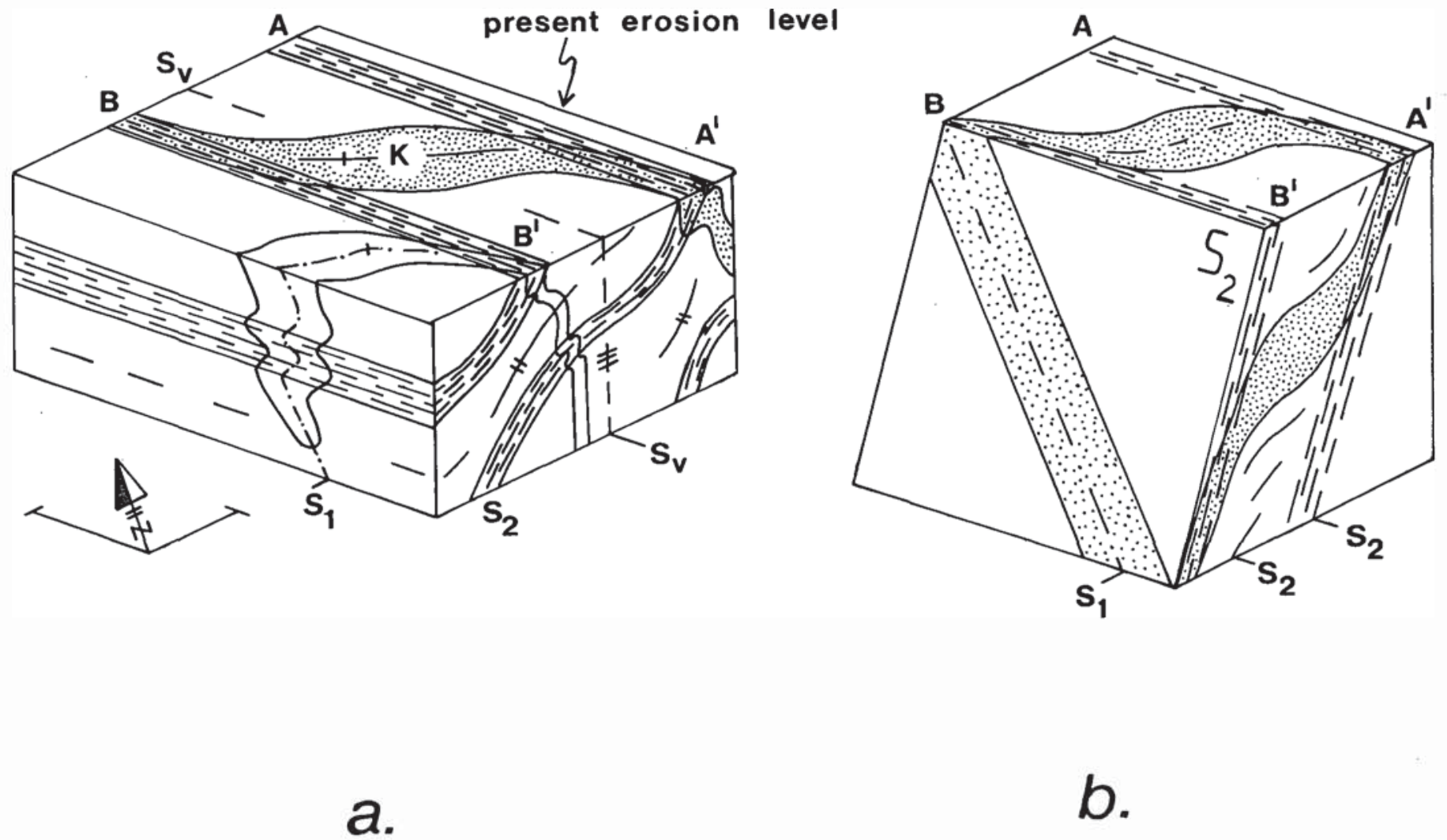

b.

Fig. 6. Interpretative sketch of the structure of the Tailings Pond quarry area; (a) postulating an upright $F_{v}$ morocline of $S_{2}$, and (b) postulating that the present structure was essentially in place before the $\mathrm{D}_{v}$ deformation. $\mathrm{AA}^{1}, \mathrm{BB}^{1}$, and $\mathrm{K}$ refer to Figure 5 ; the $\mathrm{F}_{1}$ synform is added for descriptive purposes. Option (a) is favoured. 


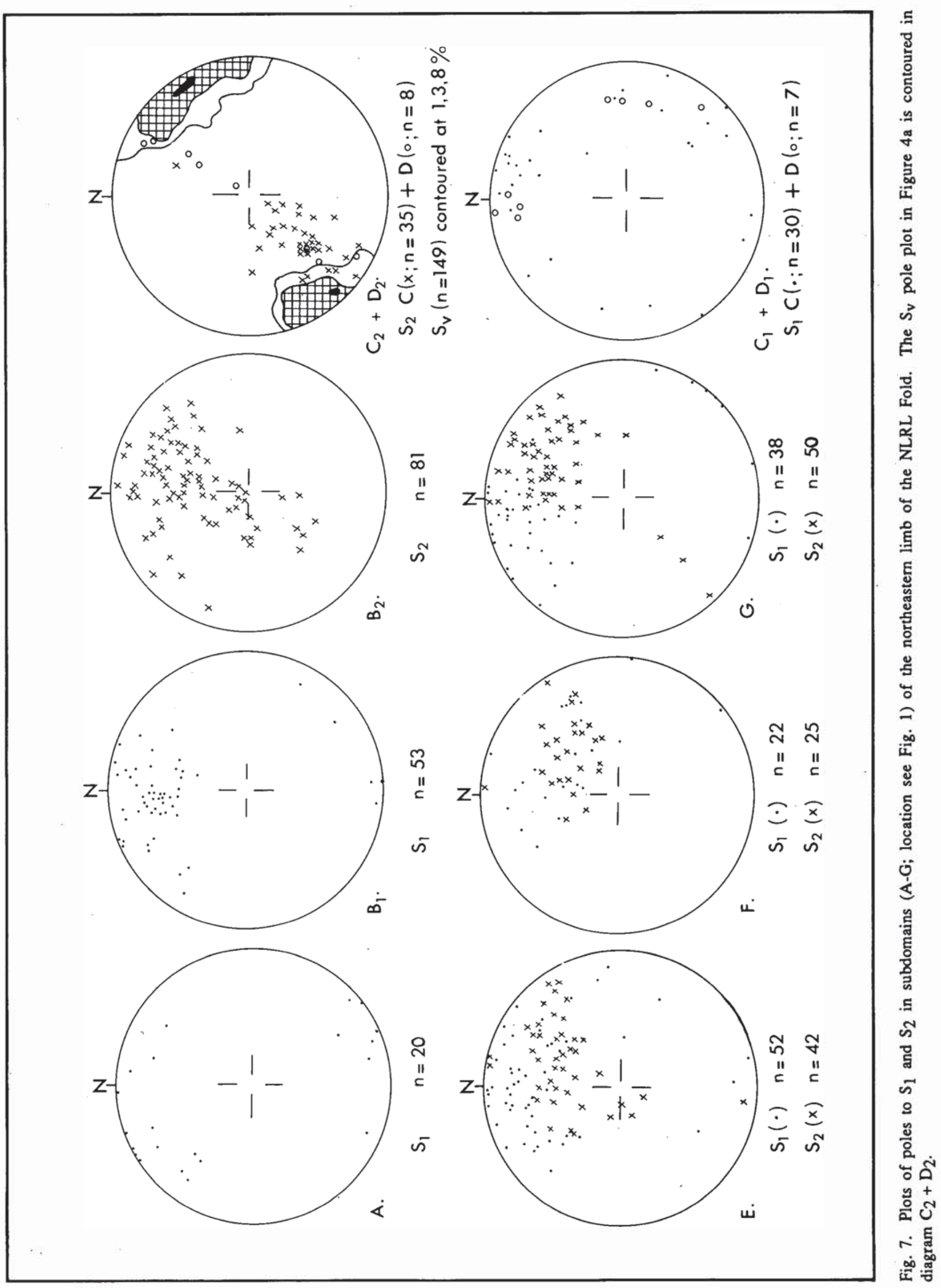


(Fig. 2, box) strike west, whereas other contacts strike parallel to the Heath Steele Fault. Both sets of strikes are exposed in subdomains $\mathrm{C}$ and $\mathrm{D}$. Conspicuously, the great circle distribution of some poles to $S_{1}$ in Figure $4 a$ is almost entirely the result of contributions from these two subdomains (Fig. $7 C_{1}+D_{1}$ ).

Readings of $\mathrm{S}_{2}$ from subdomains $\mathrm{C}$ and $\mathrm{D}$ plot in a distinct girdle with a concentration of poles in the lower left quadrant. In other subdomains, poles to $S_{2}$ are concentrated in a quadrant on the opposite side (Fig. 7 $\mathrm{B}_{2}, \mathrm{E}, \mathrm{G}$ ), so that these plots complement Figure $7 \mathrm{C}_{2}+\mathrm{D}_{2}$ to form the full girdle, shown in Figure $4 \mathrm{a}$. After contouring, the plot of poles to $\mathrm{S}_{\mathrm{v}}$ in Figure $4 \mathrm{a}$ has been incorporated in Figure $7 C_{2}+D_{2}$, to illustrate the difference in strike between $\mathrm{S}_{2}$ and $\mathrm{S}_{\mathrm{v}}$. This difference is independent of the local dip direction of $S_{2}$ (compare Fig. $7 C_{2}+D_{2}$ with Fig. 3d, e), and indicates that the girdle of poles to $\mathrm{S}_{2}$ was established independent of the $D_{v}$ deformation. The variation in dip of $S_{2}$ could be attributed to $\mathrm{F}_{\mathrm{b}}$ recumbent folding, in which case the minimal dip variation of $S_{v}$ requires that $D_{v}$ postdates $D_{h}$ (Table 1 ).

\section{THE HINGE AND SOUTHWESTERN LIMB OF THE NORTH LITTLE RIVER LAKE FOLD}

The main foliation in metasedimentary rocks and phyllites in the hinge of the NLRL Fold typically consists of a compositional layering $\left(\mathrm{S}_{0}\right)$ that is parallel to arrays of veinlets, and to a cleavage $\left(S_{1}\right)$. The main foliation is overprinted by $F_{2}$ folds with an axial plane cleavage $\left(\mathrm{S}_{2}\right)$ that dips gently to the east (Fig. 2).

In metasedimentary rocks and phyllites on the southwestern limb of the NLRL Fold (Fig. 1) the predominant attitude of $S_{1}$ has changed relative to $S_{1}$ on the northeastern limb of the NLRL Fold (compare Fig. 4a, b), and $S_{2}$ has taken over as the dominant foliation. Also, the axes of $F_{1}$ folds and associated $L_{1}$ intersection lineation are parallel to their $\mathrm{D}_{2}$ counterparts, which plunge gently (Fig. 4b). Although dip directions vary in both fold limbs, $\mathrm{S}_{2}$ on the southwestern limb of the NLRL Fold mostly dips to the northeast, as opposed to the southwesterly dip of $S_{2}$ in the mine area (Fig. 4a, b). Also, the asymmetry of most $F_{2}$ folds (as represented by Fig. $3 i$ ) is opposite to the dominant $F_{2}$ asymmetry in the mine area (as represented by Fig. 3d, e).

The reversal of the $\mathrm{F}_{2}$ fold asymmetry is accompanied by a reversal of the intersection asymmetry between $\mathrm{S}_{2}$ and $\mathrm{S}_{v}$ (compare Fig. 3d, i). $F_{v}$ folds on the southwestern limb of the NLRL Fold are open to tight, and $S_{v}$ is a weak axial plane cleavage. The orientation of $S_{v}$ and the style of $F_{v}$ folding do not vary significantly on either limb of the NLRL Fold; in both limbs $F_{v}$ fold axes plunge gently in opposite directions (Fig. 4b, c).

$D_{b}$ structures have been detected only in a small number of locations on the hinge and southwestern limb of the NLRL Fold (Fig. 4d). The $F_{b}$ folds are gentle warps or crenulations with a shallowly dipping axial plane $\left(\mathrm{S}_{\mathrm{h}}\right)$, which is represented locally by a well-developed cleavage (Fig. $3 i$ ). The $D_{b}$ deformation appears to have been similar in style in both limbs of the NLRL Fold. As in the mine area, foliations were recorded as " $S_{b \alpha}$ " in outcrops where distinction between $S_{b}$ and $S_{2}$ was impossible (Fig. 4d).

Like their counterparts in the northeastern limb, $\mathrm{F}_{5}$ folds in the southwestern limb of the NLRL Fold are open and tend to occur in groups. The folds are generally symmetrical crenulations, and their axial planar cleavage $\left(S_{s}\right)$ has a similar orientation and tectonic style to its counterpart in the mine area.

\section{THE THIRD TECTONIC DOMAIN: THE PORPHYRY POD}

$\mathrm{F}_{2}$ folds, $\mathrm{L}_{2}$ intersection lineations, and $\mathrm{S}_{2}$ cleavages are most strongly developed south of North Little River Lake (Fig. 2), where they form a northwesterly striking zone of high $\mathrm{D}_{2}$ strain. A large body of massive metarhyolite, quartz metaporphyry and metagranite borders this zone to the south, and constitutes a separate tectonic domain (the "Porphyry Pod"; Fig. 1).

A lens of pelitic metasedimentary rocks bisects this domain. The pelites are intercalated with massive metarhyolite, forming a primary layering $\left(\mathrm{S}_{0}\right)$. This layering is well developed on the outcrop scale, striking approximately northwest (Fig. 3j). Thick layers have been deformed into open, asymmetrical $F_{1}$ folds whereas thinner layers are more tightly folded, so that the $F_{1}$ folds are disharmonic. Boundaries of the folded layers tend to be quite sharp, even in the fold hinges, where phyllosilicates show a strong preferred orientation along $\mathrm{S}_{0}$.

A steeply dipping foliation $\left(S_{1}\right)$ is present in the axial planes of the $F_{1}$ folds. $S_{1}$ is a differentiated crenulation cleavage of $S_{0}$, and has been overprinted by another differentiated crenulation cleavage $\left(\mathrm{S}_{2}\right) . \mathrm{S}_{2}$ also dips steeply, and is axial planar to $\mathrm{F}_{2}$ folds of $S_{1}$ that consistently have an opposite asymmetry relative to the $F_{1}$ folds of $S_{0}$ (Fig. 2,3j). The $F_{2}$ folds have the same asymmetry as $\mathrm{F}_{2}$ folds on the opposite side of the zone of high $\mathrm{D}_{2}$ strain; i.e., on the southwestem limb of the NLRL Fold.

$F_{v}$ folds of $S_{2}$ are rare, but appear to be similar in asymmetry and style to $F_{v}$ folds on the northeastern limb of the NLRL Fold. The fold axial plane cleavage $S_{v}$ is weakly developed, but is nearly parallel to $S_{v}$ elsewhere in the region. Deviations in its orientation are interpreted to be a result of open $\mathrm{F}_{s}$ warps (Fig. 3; compare $j$ with $f) . S_{s}$ is a distinct, vertical cleavage that overprints the earlier folds, and has the same orientation and style as $\mathrm{S}_{s}$ in the two other tectonic domains (Fig. 2). $D_{b}$ structures have not been detected in the Porphyry Pod.

\section{REGIONAL LINEAMENTS}

Digital Landsat image analysis by Torrance and Lodin (1988) indicated that the region is crosscut by numerous lineaments. Most of these represent minor faults, master joints and microjoint systems, and they tend to follow the preexisting cleavage planes $\mathrm{S}_{1}-\mathrm{S}_{5}$. The dominant set of lineaments strikes northwest, and is therefore parallel to $S_{v}$ (Fig. 2). This set is marked by significant metal enrichments (J.G. Torrance, personal communication). Northwesterly striking lineaments; crosscutting the giant $\mathrm{F}_{4}$ folds of van Staal (1987; Table 1), also appear on geological maps on the scale of the Bathurst Camp (Davies, 1979), and they can be recognized on topographic maps throughout the Maritime Provinces. In Nova Scotia they are manifested as swarms of ac-joints of Devonian age, reactivated as transfer faults during opening of the Atlantic Ocean in the Triassic (Williams and $\mathrm{Hy}$, in press). 


\section{SYNTHESIS}

Early deformations $\left(D_{1}\right.$ and $\left.D_{2}\right)$

The Heath Steele sulphide deposits ("A"-"E"; Fig. 2) and prospects form part of a westerly striking belt of metasedimentary rocks and augen schists. Metasedimentary rocks in this belt occupy lensoidal domains. Augen schists to either side of these lenses are mineralogically similar, and trenching of the tips of the lenses has shown that they are closures of noncylindrical folds, rather than stratigraphic pinch-outs (Moreton, 1990).

Two major fold closures are marked by the " $\mathrm{A}$ " and " $\mathrm{C}$ " zone sulphide deposits (Fig. 2). Structural mapping of trenches and natural exposures north and south of these folds has revealed that their axial plane cleavage $\left(S_{1}\right)$ is crenulated across an $S_{2}$ cleavage overprinting both folds (Figs. 2, 3d). Hence, the folds are $D_{1}$ structures. Analysis of trenches and drill core has shown that the other three sulphide deposits are also associated with closures of $F_{1}$ folds (de Roo et al., unpublished data). These folds are tighter and smaller than the " $\mathrm{A}$ " and " $\mathrm{C}$ " zone folds. Drill core analysis and detailed mapping underground in the " $\mathrm{B}$ " zone has shown that the local $F_{1}$ fold closures have a highly noncylindrical, sheath-like, geometry, and are also transected by $\mathrm{S}_{2}$ (Moreton, 1990; our Fig. 8). The sheath-like folds occur in rocks that are strongly foliated $\left(\mathrm{S}_{1}\right)$ and lineated $\left(\mathrm{L}_{1}\right)$, and the augen schists in particular can be described as mylonites on the basis of their microstructure (de Roo and Williams, unpublished data). The L/ $\mathrm{S}$ tectonites, the mesoscopic $\mathrm{F}_{1}$ transposition, and the sheath-like folds indicate that the belt of augen schists, metasedimentary rocks and sulphide enrichment is a $D_{1}$ shear zone.

The $\mathrm{D}_{1}$ shear zone is bound to the south by a tectonic contact (Dechow, 1960; McBride, 1976; Owsiacki, 1980). This contact (the Heath Steele Fault; Fig. 2) is the locus of relatively strong brittle-ductile $D_{1}$ deformation, separating the shear zone from felsic schists and phyllites, and massive metadiabase. To the north, the shear zone is bounded by relatively undeformed metaagglomerate, felsic phyllite and metadiabase (Fig. 1).

A similar tectonic setting is exposed in the Tailings Pond quarries (Fig. 5), where highly deformed metasedimentary rocks are also separated by felsic schists and phyllites from weakly deformed metadiabase to either side. In this area, lithological contacts $\left(\mathrm{S}_{0}\right)$ are parallel to $\mathrm{S}_{1}$ (Fig. $5 ; \mathrm{S}_{1}$ form lines), and both are overprinted by a crenulation cleavage $\left(S_{2}\right)$ with a different strike. Locally however, $S_{0}$ and $S_{1}$ have been transposed into $S_{2}$ (Fig. 5; zones $\mathrm{AA}^{1}$ and $\left.\mathrm{BB}^{1}\right)$. The transposition in these zones was accompanied by attenuation and boudinage of the primary layering, so that both $\mathrm{D}_{2}$ shear zones form the long limbs of a macroscopic $F_{2}$ fold. This fold has the same asymmetry as mesoscopic $\mathrm{F}_{2}$ folds.

The overall $\mathrm{F}_{2}$ asymmetry in the Tailings Pond quarries is the same as in the mine area (Figs. 2, 8), but mesoscopic $\mathrm{F}_{2}$ folds of $S_{1}$ on the southwestern limb of the NLRL Fold have an opposite asymmetry (Figs. 2, 3i). Also, $F_{2}$ folds of $S_{1}$ in the hinge of the NLRL Fold are symmetrical, so $S_{1}$ predates this fold. Since $S_{1}$ is parallel to the compositional layering $\left(\mathrm{S}_{0}\right)$ in outcrops in both limbs of the NLRL Fold, the enveloping surface of $S_{1}$ is assumed to be parallel to the trend of lithological contacts across the NLRL

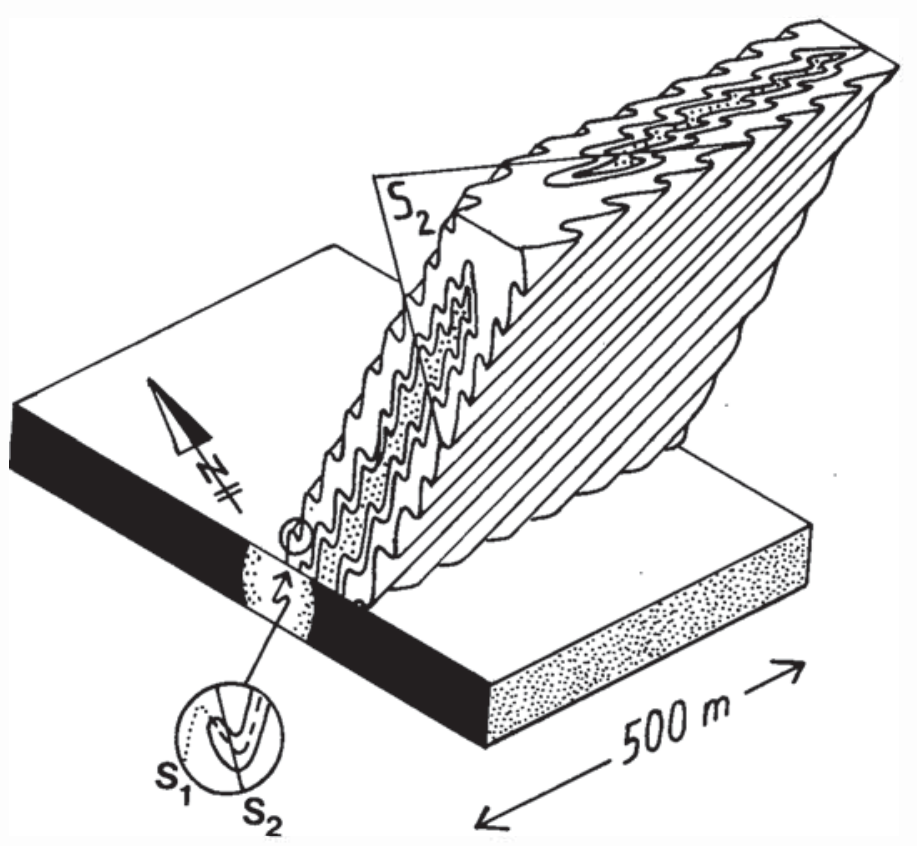

Fig. 8. Schematic structure of the "B" zone ore deposit (slab on horizontal pedestal), after Moreton (1990). The slab of ore symbolizes the enveloping surface of the steeply north dipping main foliation $\left(S_{1}\right)$, which is axial plane to intrafolial $F_{1}$ folds, both on the small scale (inset) and on the large scale (the isoclinal antiform marked by metasedimentary rocks (stipple) within the slab). This dome of metasedimentary rocks has a westerly plunging axis, and is deformed into a cascade of westerly plunging $F_{2}$ folds with a southwesterly dipping axial plane cleavage $\mathrm{S}_{2}$.

Fold. It follows that the belt of metasedimentary rocks and augen schists southeast of North Little River Lake can be regarded as the continuation of the $D_{1}$ shear zone at Heath Steele Mines.

The (a)symmetry of the second-order $F_{2}$ folds suggest that the NLRL Fold is an $\mathrm{F}_{2}$ structure, although the predominant dip direction of $\mathrm{S}_{2}$ planes reverses across this fold, from southsouthwesterly in its northeastern limb (Fig. 4a) to north-northeasterly on the other limb (Fig. 4b). On the northeastern limb of the NLRL Fold, the dip of $S_{2}$ varies from gentle to steep (Figs. $3 g$, b-f, $4 a$, respectively), and $S_{2}$ is axial planar to both steeply inclined and nearly recumbent folds. $F_{2}$ recumbent folds and local transposition of $S_{1}$ have also been recognized in areas to the northwest and southwest of Heath Steele Mines (Helmstaedt, 1971; Irrinki, 1986; Table 1). Northeast of Heath Steele Mines, $F_{2}$ folds are upright with axial planes steeply dipping to the west. Van Staal (1987) correlated this zone of upright $F_{2}$ folding with the zone of recumbent $\mathrm{F}_{2}$ folding, and referred to them as "steep belts" and "flat belts", respectively (Table 1). The presence of overturned, noncylindrical $F_{1}$ folds in the steep belt at Brunswick Mines (van Staal and Williams, 1984; van Staal, 1985) illustrates the regional consistency of $D_{1} / D_{2}$ structural relationships (compare with Fig. 8).

The dip of $\mathrm{S}_{2}$ in the Tailings Pond quarries is greatest in the $\mathrm{D}_{2}$ shear zones (Fig. 6), which therefore can be considered as small-scale $D_{2}$ steep belts. A steep belt with steeply dipping $S_{2}$ 
cleavages and gently plunging fold axes is also developed south of North Little River Lake (Fig. 2). This zone of high strain occupies the attenuated, southwestern limb of the NLRL Fold.

\section{Late deformations $\left(D_{3}, D_{4}\right.$ and $\left.D_{5}\right)$}

On the outcrop scale, the variation in dip of $\mathrm{S}_{2}$ is clearly the product of three stages of folding $\left(D_{v}, D_{b}, D_{s}\right)$. Considering the limited variation in the orientation of $\mathrm{S}_{\mathrm{v}}$ and $\mathrm{S}_{\mathrm{b}}$ surfaces (Fig. 4), the $\mathrm{D}_{5}$ deformation appears to be localized, although, according to mapping by one of us (van Staal), the giant, open folds that dominate the structure of the Bathurst Camp (i.e., the Tetagouche Lakes and Nine Mile Brook Folds; Skinner, 1974) are Fs structures in our classification (Table 1). The $\mathrm{D}_{s}$ deformation is distinct in style. Also, the orientation of the $\mathrm{S}_{5}$ cleavage is independent of its position in any fold, including the NLRL Fold (Figs. 2,4d), and does not vary throughout the region. Although the $\mathrm{D}_{\mathrm{s}}$ structures clearly postdate all others in outcrop, timing relationships between the other two late deformations $\left(D_{v}\right.$ and $\left.D_{b}\right)$ are inconclusive, which complicates the correlation of smallscale interference patterns in $\mathrm{S}_{2}$ with the large-scale structure of $\mathrm{S}_{2}$.
The $D_{y}$ deformation produced mostly open folds with a northwesterly striking axial plane cleavage $S_{v}$, whereas the $D_{b}$ deformation produced mostly gentle, recumbent, folds. The pole figures for $\mathrm{S}_{\mathrm{v}}$ and $\mathrm{S}_{\mathrm{h}}$ each show clear clusters of poles, and in both limbs of the NLRL Fold, plots of $\mathrm{L}_{v}$, and of poles to $S_{v}$, look the same (Fig. 4; compare a and $c$ with b), as do plots of poles to $S_{b}$ (Fig. 4d; compare $S_{b}$ with $S_{b a r}$ ). On the basis of style the $D_{v}$ structures can be correlated as a third generation $\left(\mathrm{D}_{3}\right)$ across the Bathurst Camp, whereas $\mathrm{F}_{\mathrm{h}}$ recumbent folds are either late, or not recorded (Table 1).

The strike of $S_{2}$ varies at least 90 degrees relative to $S_{v}$ in separate trenches (Fig. 3d, $\mathrm{f}$ ), indicating the presence of $F_{v}$ folds of a size, greater than the scale of both trenches. However, the difference in strike between $S_{2}$ and $S_{v}$, and, consequently, the sense of asymmetry of $F_{v}$ folds of $S_{2}$, is independent of the dip direction of $\mathrm{S}_{2}$ (Fig. 3d, e). This problem could be resolved by invoking a variation in plunge direction of $F_{v}$ folds (Fig. 4c), but conical $F_{v}$ folding fails to explain why $F_{2}$ folds of $S_{1}$ show an $S$ asymmetry, irrespective of the dip direction of $\mathrm{S}_{2}$ (Figs. 3d, e, 8). The $\mathrm{F}_{2}$ asymmetry and the orientation of $\mathrm{S}_{2}$ can be explained more simply by $F_{b}$ recumbent folding of $S_{2}$ prior to the $D_{v}$ deformation (Fig. 9). This model also explains the observed
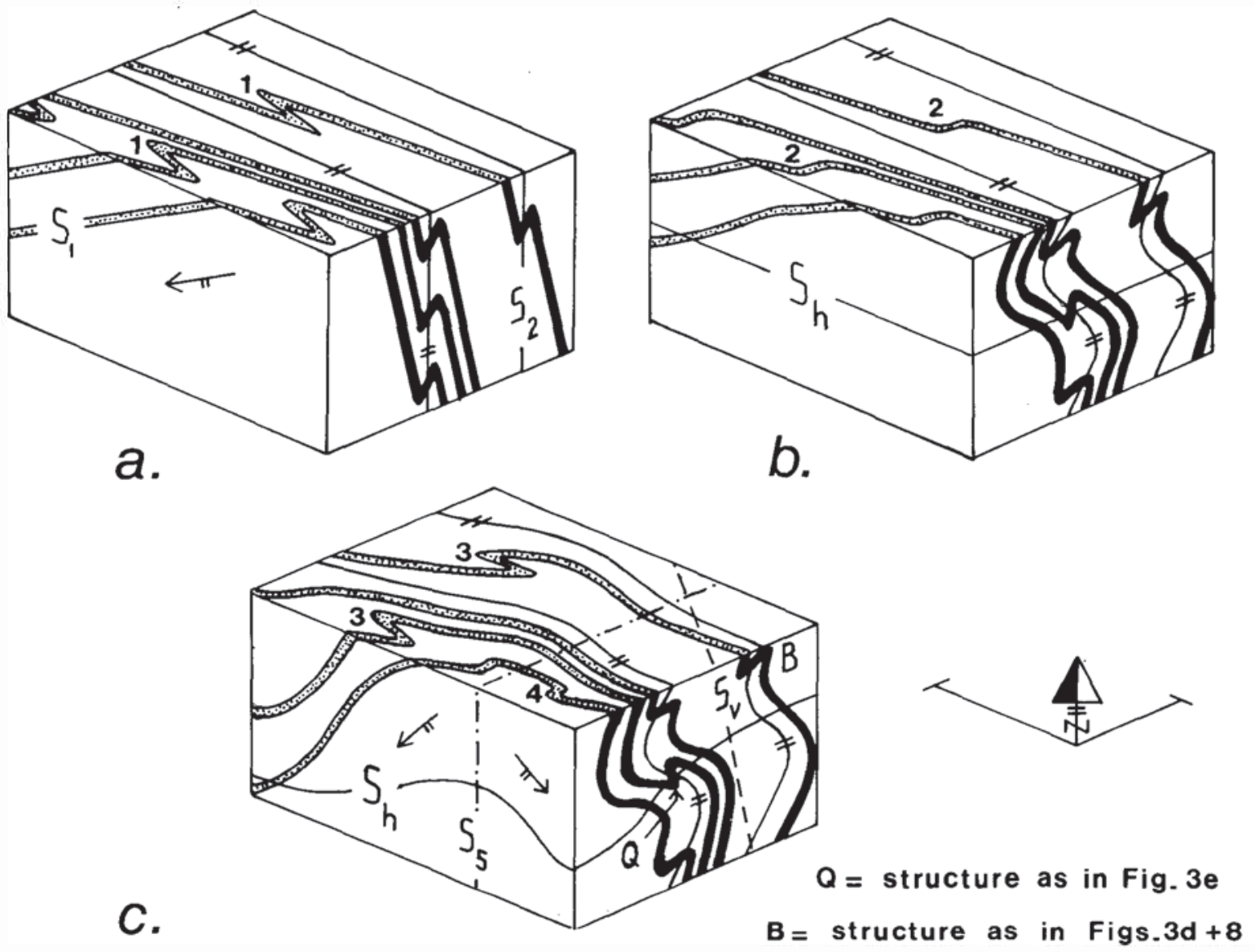

Fig. 9. A model of the structural evolution at $C$ and $D$ in Figure 1, showing $F_{2}$ folds of the main foliation $\left(S_{0}=S_{1}\right)$ in (a). In (b), $S_{2}$ is deformed in an $F_{b}$ recumbent fold. In (c), the axial plane of this fold, $S_{b}$, is cast into a dome and basin pattern because of $F_{v}$ and $F_{5}$ folding. This model assumes that $F_{2}$ folds originally plunged to the west, and shows them as cylindrical for simplicity. Structural symbols refer to Figure 2 . Note that $F_{2}$ folds (1-3) are "unfolded" in (b), only to reappear in (c). This is a function of the rotation of their hinge and axial plane, as can be checked by folding a slip of paper (representing $\mathrm{S}_{1}$ ), and then intersecting it with the erosion horizon while rotating the paper. 
variation in plunge direction of $\mathrm{D}_{2}$ fold axes and intersection lineations in the mine area (Fig. 4a; also compare the asymmetry of fold 4 in Fig. 9c with Fig. 3a). The prevailing S-asymmetry of $F_{2}$ folds in outcrop is interpreted as reflecting original $S_{1} / S_{2}$ intersection relationships (Fig. 9a).

Structural models of the NLRL Fold suffer from the same overprinting difficulties. In opposite limbs of this fold, the asymmetry of $\mathrm{F}_{2}$ folds of $\mathrm{S}_{1}$ is reversed, but so is the asymmetry of $F_{v}$ crenulations of $S_{2}$. These relationships could be explained by assuming that the macroscopic $\mathrm{F}_{2}$ asymmetry reversal is apparent, and in fact reflects the surface projection of a dip reversal of the $F_{2}$ fold axial planes $\left(S_{2}\right)$ across an upright $F_{v}$ synform of $\mathrm{S}_{2}$ (Fig. 10a). Using this model, we have difficulty explaining the structure of the "Porphyry Pod" south of North Little River Lake.

On the basis of the dominant asymmetry of $S_{2}$ relative to $S_{1}$, the Porphyry Pod is part of the southwestern limb of the NLRL Fold (Figs. 2, 3j), although it is separated from the main belt of metasedimentary rocks and augen schists by a zone of high $\mathrm{D}_{2}$ strain. $S_{v}$ in the Porphyry Pod has an attitude relative to $S_{2}$ that is the reverse of the $S_{2} / S_{v}$ asymmetry on the opposite side of the zone of high strain (compare Fig. 3i, j), but is the same as in the mine area (compare Fig. 3d, j). These relationships require that $\mathrm{S}_{\mathrm{v}}$ crosscuts the NLRL Fold (Fig. 1, upper part; dashes), and argue against the possibility that this fold is an $F_{v}$ structure, unless the zone of high $\mathrm{D}_{2}$ strain is the locus of a major fault, in which case the structure of the Porphyry Pod has no bearing on the model of the NLRL Fold. Most $\mathrm{D}_{2}$ and $\mathrm{D}_{1}$ fold axes and lineations on the southwestern limb of the NLRL Fold, including the zone of high strain, plunge in a different direction to the $\mathrm{F}_{\mathrm{v}}$ fold axes (Fig. 4b). This substantiates the model of transection of the NLRL Fold by $S_{v}$. Our preferred explanation of the $F_{v}$ asymmetry reversal across the fold assumes, as in Figure 9, that the $D_{b}$ deformation predated the $\mathrm{D}_{\mathrm{v}}$ deformation (Fig. 10b, Table 1). In this scenario, the overprinted cleavage in the $F_{v}$ folds northwest and southeast of North Little River Lake could be interpreted conveniently as $S_{b}$ instead of $S_{2}$, so that there would no longer be a change in asymmetry of $F_{v}$ folds of $S_{2}$ across the NLRL Fold. Consequently, only the $F_{2}$ asymmetry reversal remains, so that the NLRL Fold can be defined as an $F_{2}$ fold (Figs. 1, 10c). According to the dominant $S_{1} / S_{2}$ asymmetry in the mine area (Fig. 10c, right hand side of frontal section; compare with Fig.9a) this fold must be a northwesterly plunging antiform, although $\mathrm{D}_{2}$ linear element distributions and the $S_{1}$ pole figure indicate a southeasterly plunge (Fig. 4b). The plunge variation could be attributed to post- $\mathrm{D}_{2}$ deformation. Firstly, the axial plane of the $\mathrm{F}_{2}$ fold has been warped in folds with gently dipping axial planes $\left(S_{b}\right)$. Subsequently, $S_{h}$ was deformed into a northwesterly striking $F_{v}$ synform (Fig. 10b) with a steeply dipping $S_{v}$ cleavage that crosscuts the refolded $\mathrm{F}_{2}$ NLRL Fold (Figs. 1, 10c). This fold was contorted even further in the $\mathrm{D}_{5}$ deformation.

In this model, the Porphyry Pod can be considered as part of the southwestern limb of the $\mathrm{F}_{2}$ NLRL Fold. Hence, assuming it persists along strike on, or below, the present erosion level, the Porphyry Pod can be traced around the $\mathrm{F}_{2}$ fold (Fig. 1, upper part; stipple trail). In this case, the massive metarhyolite, quartz metaporphyry, and the intercalated lenses of metasedimentary
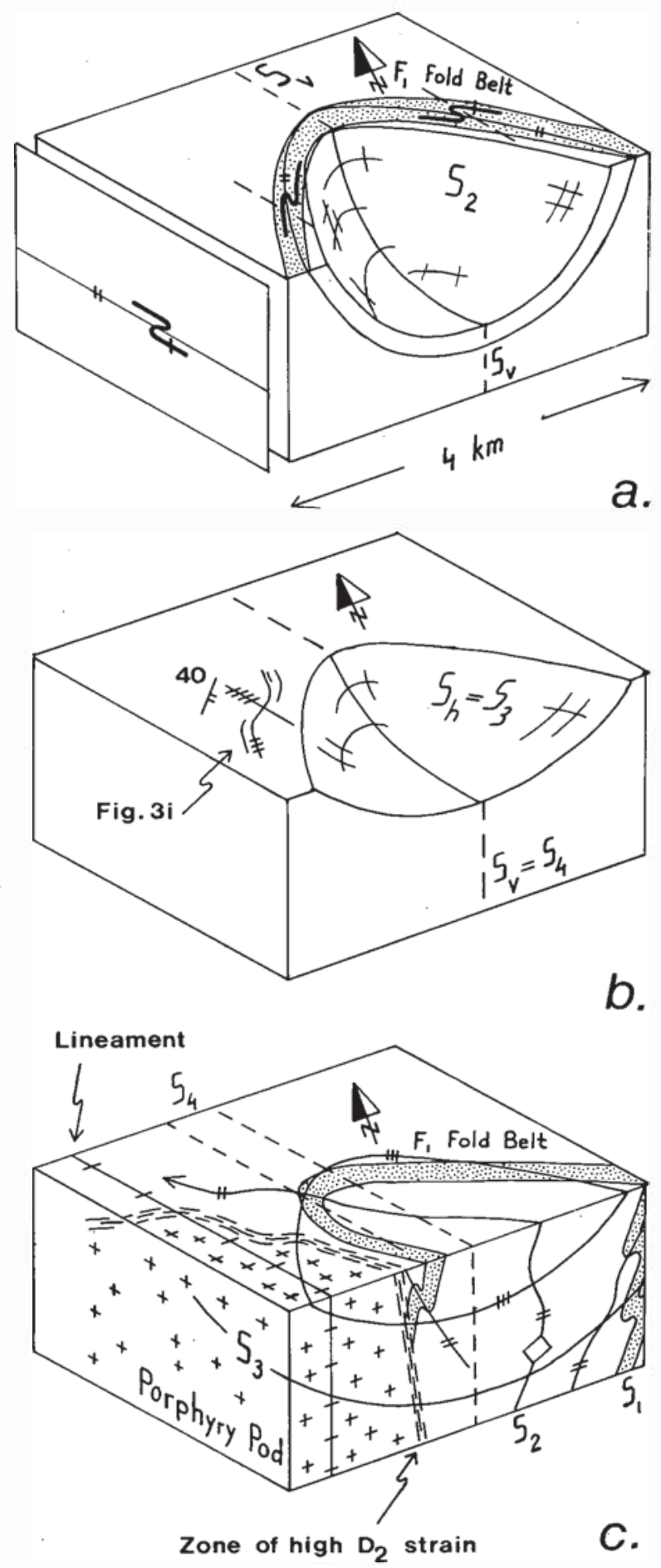

Fig. 10. (a) One explanation for the reversal of the $F_{2}$ and $F_{v}$ fold asymmetry across the limbs of the NLRL Fold is an $F_{v}$ synform of $S_{2}$, which originally was axial plane of recumbent, asymmetrical $F_{2}$ folds of $S_{1}$ (as shown in front panel). Prevalent dip directions of $S_{2}$ require that the $F_{v}$ synform plunges to the southeast. (b) Same area, assuming $S_{b}$ $\left(\right.$ " $\mathrm{S}_{3}$ ") predates $\mathrm{S}_{4}\left(\right.$ " $\mathrm{S}_{4}$ "), in which case overprinting relationships in Figure $3 i$ can be reinterpreted. Comparison with actual $S_{b}$ orientations shows that the " $\mathrm{F}_{4}$ " fold of " $\mathrm{S}_{3}$ " must be a gentle synform. (c) As (b), incorporating pre- " $D_{3}$ " structures. Here, the $F_{2}$ asymmetry in section requires that the NLRL Fold is a northwesterly plunging $F_{2}$ antiform (compare with Figure 9a). Unlabeled form surface symbols refer to Figure 2. 
rocks in the Porphyry Pod could be related to petrographically similar rocks north of the $D_{1}$ shear zone in the mine area.

\section{ACKNOWLEDGEMENTS}

We enjoyed the cooperation of geologists from Heath Steele Mines and Noranda Exploration, in particular Don Archibald and Joe Deveaux. We also thank Steve Lucas for critically reading the manuscript. This paper is a contribution to the Canada - New Brunswick Mineral Development Agreement 1984-1989. Moreton and de Roo acknowledge financial support under this Agreement. Williams acknowledges financial support from the Natural Science and Engineering Research Council.

BEVIER, M.L. 1988. U-Pb geochronologic studies of igneous rocks in N.B. In Thirteenth annual review of activities, project resumés. Edited by S.A. Abbott. Department of Natural Resources and Energy, New Brunswick, pp. 134-140.

DAVIES, J.L. 1979. Geological map of northern New Brunswick. New Brunswick Department of Natural Resources, Mineral Resources Branch, Map NR-3.

DAVIES, J.L., FYFFE, L.R., and McALLISTER, A.L. 1983. Geology and massive sulphides of the Bathurst area, New Brunswick. In Field trip guidebook to stratabound sulphide deposits, Bathurst area, N.B., Canada and west-central New England, U.S.A. Edited by D.F. Sangster. Geological Survey of Canada Miscellaneous Reports 36, pp. 1-30.

DECHOW, E. 1960. Geology, sulfur isotopes and the origin of the Heath Steele ore deposits, Newcastle, N.B., Canada. Economic Geology, 55, pp. 539-556.

FRANKLIN, J.M., LYDON, J.W., and SANGSTER, D.F. 1981. Volcanic-associated massive sulphide deposits. Economic Geology 75th Anniversary Volume, pp. 485-627.

FYFFE, L.R., IRRINKI, R.R., and CORMIER, R.F. 1977. A radiometric age of deformed granitic rocks in north-central New Brunswick. Canadian Journal of Earth Sciences, 14, pp. 1687-1689.

FYFFE, L.R., PAJARI, G.E., Jr., and CHERRY, M.E. 1981. The Acadian plutonic rocks of New Brunswick. Maritime Sediments and Atlantic Geology, 17, pp. 23-36.

HARLEY, D.N. 1979. A mineralized Ordovician resurgent caldera complex in the Bathurst-Newcastle Mining District, New Brunswick, Canada. Economic Geology, 74, pp. 786-796.

HELMSTAEDT, H. 1970. Geology of map area 0-6; head of Middle River and Wildcat Brook (Northern New Brunswick). New Brunswick Department of Natural Resources, Mineral Resources Branch, Map Report 70-1, 17 p.

- 1971. Structural geology of Portage Lakes area, Bathurst Newcastle districh, New Brunswick. Geological Survey of Canada, Paper 70-28, 52 p.

IRRINKI, R.R. 1986. Geology of Big Bald Mountain map area (NTS
21 0/1), New Brunswick. New Brunswick Department of Forests, Mines and Energy, Mineral Resources Division, Map Report 86-2, $55 \mathrm{p}$.

MALTMAN, A.J. 1981. Primary bedding-parallel fabrics in structural geology. Journal of the Geological Society of London, 138, pp. 475-483.

McALLISTER, A.L. 1960. Massive sulphide deposits in New Brunswick. Canadian Institution of Mining and Metallurgy Bulletin, 53, No. 574, pp. 88-98.

McBRIDE, D.E. 1976. The structure and stratigraphy of the B-zone, Heath Steele Mines, Newcastle, New Brunswick. Unpublished $\mathrm{Ph}$.D. thesis, University of New Brunswick, Fredericton, $227 \mathrm{p}$.

MORETON, C. 1990. The stratigraphy and structure of the B, $B_{5}$ and Ezone massive sulphide deposits at Heath Steele Mines, Newcastle, New Brunswick, Canada. Unpublished Ph.D. thesis, University of New Brunswick, Fredericton.

MORETON, C. and WILLIAMS, P.F. 1986. Structural and stratigraphic relationships at the B-zone orebody, Heath Steele Mines, Newcastle, New Brunswick. Current Research, Part B, Geological Survey of Canada, pp. 57-64.

OWSIACKI, L. 1980. The geology of the C-zone, Heath Steele Mine, New Brunswick. Unpublished M.Sc. thesis, University of New Brunswick, Fredericton, $226 \mathrm{p}$.

SKINNER, R. 1974. Geology of Tetagouche Lakes, Bathurst, and Nepisiguit Falls map-areas, New Brunswick. Geological Survey of Canada, Memoir 371, 133 p.

Van STAAL, C.R. 1985. Structure and metamorphism of the Brunswick Mines area, Bathurst, New Brunswick, Canada. Unpublished Ph.D. thesis, University of New Brunswick, Fredericton. $484 \mathrm{p}$.

1987. Tectonic setting of the Tetagouche Group in northem New Brunswick: Implications for plate tectonic models of the northern Appalachians. Canadian Joumal of Earth Sciences, 24, pp. 1329-1351.

Van STAAL, C.R. and WILLIAMS, P.F. 1984. Structure, origin and concentration of the Brunswick No. 12 and No. 6 orebodies. Economic Geology, 79, pp. 1669-1692.

TORRANCE, J.G. and LODIN, M. 1988. Application of satellite and airborne geophysical imagery in the search for massive sulphide deposits, Heath Steele area, New Brunswick, Canada. New Brunswick Department of Natural Resources and Energy, Minerals and Energy Division, Open File Report 88-23, 23 p.

WEBER, K. 1981. Kinematic and metamorphic aspects of cleavage formation in very low-grade metamorphic slates. Tectonophysics, 78, pp. 291-306.

WILLIAMS, P.F. 1972. Development of metamorphic layering and cleavage in low-grade metamorphic rocks at Bermagui, Australia. American Journal of Science, 272, pp. 1-47.

WILLIAMS, P.F. and HY, C. In press. Origin, deformational and metamorphic history of gold-bearing veins on the eastern shore of Nova Scotia. Geological Survey of Canada, Special Volume. 